International Journal of Social Science and Economic Research

ISSN: 2455-8834

Volume:06, Issue:05 "May 2021"

\title{
THE GREAT EXODUS: THE ECONOMIC, SOCIAL, AND CULTURAL COSTS OF THE PARTITION OF INDIA
}

\author{
Jahaan Sahgal \\ The Doon School Dehradun, Uttarakhand
}

DOI: 10.46609/IJSSER.2021.v06i05.016 URL: https://doi.org/10.46609/IJSSER.2021.v06i05.016

\begin{abstract}
The Partition of India refers to the division of the British colony of India into two independent nation-states, India and Pakistan in 1947. This paper has explored the core social conflicts that gave rise to the Two Nation theory and eventually caused the partition of India. Religious divides were often a result of British policies that were designed to achieve this outcome and were often fueled by political differences between major figures in the independence movement. The shortterm impact of the partition in terms of the loss of life and property and trauma combined with its long-term contribution to the deterioration of the social fabric in the Indian subcontinent have been contrasted with its ideological justification. This paper has sought to identify commonalities and links between polarizing political narratives that existed amongst both Hindus and Muslims during the time of partition with the rhetoric of contemporary right-wing populist leaders and parties in India to bring attention to the potential harms of religious nationalism in the Indian subcontinent.
\end{abstract}

Keywords: Economic, Culture, Social, Property, independence.

\section{Introduction}

The Indian subcontinent shares a rich cultural and historical heritage, with the present nationstates that constitute it being a part of a common culture and often the same empire through the course of history. The British Government adopted control over the Indian subcontinent after the Revolt of 1857, which ended the rule of the British East India Company (which had, in turn, annexed large parts of land from the declining Muhal empire) (Khan, 1940). The struggle against British rule continued well beyond 1857 and emerged against one of the largest non-violent movements in history for self-assertion and independence. Whilst the peoples of this land achieved independence, it came at the cost of partitioning erstwhile British India into two independent states- an Islamic theocracy- Pakistan, and a secular progressive democracy - India. 


\section{International Journal of Social Science and Economic Research}

ISSN: $2455-8834$

Volume:06, Issue:05 "May 2021"

The partition was based on incompatible religions and cultures of Hindus (then defined as all non-Christian and non-Muslim peoples of India, including Buddhists, Sikhs, and tribals) and Muslims. Even though religion was one of the many identity markers in Indian society (which had multiple levels of social and economic hierarchy), the emphasis on religious differences was purposely created by both Hindu and Muslim leaders to maintain control and hegemony over narratives in their communities (Tablot \& Singh, 2009). The British saw the growing unity between Hindus and Muslims (which was the reason behind the success of the First War of Independence in 1857) as a threat to their power, and intentionally sought to introduce policies and programs that turn one community against another, as well as support polarizing local leaders as compared to those that delivered secular or unifying messages. The systematic efforts of the British for almost a century paid off, with partition being one of the primary conditions for independence from the British, as established by prominent leaders of the Muslim community (Zamindar, 2013). This was complemented by the rise of Hindu right-wing outfits who demanded preferential treatment against Muslims, and the combination of these polarizing narratives between major religious communities with improper planning and implementation of partition plans made the actual partition process one of the bloodiest events in the history of the subcontinent. Moreover, it has fundamentally changed the geopolitics and culture in this region in the long term, as historical and present conflicts between Hindus and Muslims continue to dictate key political and social narratives in present-day India, Pakistan, and Bangladesh (formerly East Pakistan) (Bates, 2011).

It should also be understood that the partition of India was not a swift and immediate process. Hindus, Sikhs, and Muslims who found themselves in the 'wrong country' had to make a tough decision that presented life-threatening risks regardless of the choice. Muslims were promised the position of equal citizens in India by their leaders who opposed partition, and yet anxieties surrounding minority positions fueled by polarizing rhetoric forced many to take a risky and unrealistic journey across the border. Similarly, whilst Hindus were promised protection and rights in Pakistan, the fears of a theocratic Islamic government forced many to make that choice (Zamindar, 2013). This process continued for more than four years after the partition was first announced. Despite rare reports of peace and cooperation, the partition saw unprecedented levels of religious violence in the region.

It can be argued that the long-term negative consequences of partition are even worse. Independent India and Pakistan have fought 3 wars between them, losing thousands of military and civilian lives in the process. Kashmir became and continues to be a conflicted region, which has possibly seen the worst long-term consequences, particularly in terms of the violation of human rights (perpetuated by both the Indian and Pakistani Governments) (Talbot \& Singh, 2011). Lastly, it has contributed to a feeling of animosity between the two religious 


\section{International Journal of Social Science and Economic Research}

ISSN: $2455-8834$

Volume:06, Issue:05 "May 2021"

communities, with polarization contributing to hate crimes and discriminatory and oppressive policies- even in the 21 st century.

\section{Background}

The intellectual backing to the idea of partition came from the 'Two Nation Theory'- an idea propagated by both Hindu and Muslim leaders that states that there are fundamental, irreconcilable differences between Hindus and Muslims which makes it impossible for both these religions to coexist within the same self-governing, independent nation-state (Khan, 1940). Religion has always been a very important identity marker for individuals in South-East Asia (which could be attributed to the higher levels of religious diversity in the region). The idea of religion dictating the nationality of people was first adopted by Hindu leaders including Bhai Premchand, Rajnarayan Basu, and Nabagopal Mitra at the end of the 19th century (Ambedkar, 1940). Muhammad Ali Jinnah, a Muslim lawyer and ex-member of the Indian National Congress, who was first a staunch supporter of religious unity, popularized these ideas in the Muslim community after coming under the influence of the poet Muhammad Iqbal, and used his teachings as a call for the awakening of Muslims, launching a movement that would culminate in the formation of Pakistan, as an Islamic theocracy (O Brien \& Cruise, 1998). The Two Nation theory has also been used by Hindu Nationalist groups in India, under the leadership of V. Savarkar to justify their demands for converting India from a secular nation into a Hindu State (Savarkar, 1940). The process of galvanizing support behind partition was difficult, and even Jinnah had been referred to by many of his Hindu colleagues in the Congress as 'an ambassador of Hindu Muslim unity (Singh, 2009). However, leaders were able to play on the anxieties of the Muslim community, which feared oppression in a state where they had minority status. Despite staunch opposition from the Indian National Congress, the Two Nation Theory received support from the British (and eventually from the congress), and it prevailed in practice because of the threat of wide-scale religious violence in a former colony.

Millions of Hindus, Sikhs, and Muslims decided to flee their homes (which, in most cases were generational) in fear of religious persecution. Once the lines of division were drawn, about 14.5 million people crossed the borders, primarily in Punjab and Bengal which had the most religiously diverse populations in British India. (Gatrell, 2013). Reports suggest that 6.5 million Muslims migrated from India to West Pakistan (now Pakistan) and 4.7 million Hindus and Sikhs migrated from West Pakistan to India. Similarly 2.6 million migrated from India to East Pakistan (now Bangladesh) and 0.7 million did the opposite. The British government and even Hindu and Muslim leaders did not anticipate these population exchanges and found themselves ill-prepared to facilitate them. They were hence marked by violence to an extent that has since been described as retributive genocide (Brass, 2003). People relocating from land that had been theirs 


\section{International Journal of Social Science and Economic Research}

ISSN: $2455-8834$

Volume:06, Issue:05 "May 2021"

for generations to escape communal violence ended up facing some of the worst consequences of it, which were made worse because of the inaction of the authorities. Estimates of deaths caused due to the Partition lie between 200,000 to 2,000,000 (Butalia, 2000). Given that this violence was mostly motivated by vengeance, it created a cycle of atrocities inflicted by the Hindu and Muslim communities upon each other (Jain, 1987). It has also been reported that many acts of violence and massacres were organized by Hindu and Muslim right-wing political outfits(Sikand, 2004). The Partition is said to have displaced over 10 million people (Talbot \& Singh, 2009), with millions continuing migration well beyond independence and the Partition through the 1950s and 1960s. (Khalidi, 1998). The worst impact of the Partition, however, was felt by women of all religious communities. Violence was accompanied by attempts to seize the material possessions of their victims, and women were defined by both Hindu and Muslim rioters as the most valuable possession of the opposing group. In line with this ideology, mass rapes were systematically committed to ensuring the 'survival' of the community through forced pregnancies and childbirth (Butalia, 2000). Such incidents shed light on feminist perspectives on war, which explain how women are most often the worst sufferers during times of violent conflict war even though they are seldom directly involved in the process of causing it (Wood, 2000).

\section{Discussion}

The partition has had ulaterable impacts on the demography, society, culture, and economy of India. According to the 1951 Census of India, 2\% of India's population were refugees who came to the country from East and West Pakistan. Delhi received the largest number of refugees for a single city, with its population doubling between 1941 and 1951 (Kaur, 2007). Refugees were housed in temporary camps set around Delhi, which were subsequently converted into permanent housing through extensive building projects undertaken by the Government of India from 1948. Important contemporary housing colonies and residential areas in Delhi came up after partition, including Lajpat Nagar, Rajinder Nagar, Punjabi Bagh, and Kingsway Camp. The vibrant culture of Delhi was further enhanced by the settlement of (mostly Sikh and Punjabi) migrants, who have since contributed immensely to the local and national economy. Demographic shifts were witnessed across the country- such as Hindu migrants fleeing to the Andaman and Nicobar Islands and eventually making Bengali the most spoken language there, and the influence of Sindhi immigrants on the cultures of Mumbai and Gujarat (Johari, 2018).

The long-term political impact of the partition has been subject to intensive debates over the past decades. India particularly emerged as a stable and secular democracy- something that is extremely rare when it comes to former colonies with heterogeneous populations. Religious divisions continued to exist, and religious extremism did contribute to the assassination of 


\section{International Journal of Social Science and Economic Research}

ISSN: $2455-8834$

Volume:06, Issue:05 "May 2021"

Gandhi, but such sentiments were largely controlled which prevented social disturbances from threatening the moral and governing fabric of the country (Cohen, 2004). Nationalism in India was centered around the constitution and the motherland and not along religious lines, which allowed for inclusivity both in the government and also in society. India soon saw itself in the middle of two wars, neither of which had a decisive outcome on the fate of the country but both of which saw individuals of all communities contributing selflessly to the national effort. Moreover, the presence of caste and sect divisions amongst Hindus prevented them from organizing as a vote bank during elections and deterred religious polarization. When violence did break out along religious lines, such as the events post the assassination of Indira Gandhi, it was contained with efficiency before it could threaten the state structure or cause unalterable damages to the social structure (Cesari 2014).

However, this began to change in the 1990s, with the resurgence of right-wing Hindutva outfits. Even though they continued to exist after independence, their impact on political parties and election results were very restricted. However, there was a sentiment in the country that regarded the secular and socialist Indian National Congress government as one that appeased minorities and deprioritized the rights of Hindus (especially after the Shah Bano case). This was accompanied by the repetitive efforts of organizations like the Rashtriya Swayamsevak Sangh (RSS) to foster a common Hindu identity detached from the lines of caste and sect. The disturbance around the demolition of the Babri Masjid and demands for the 're-construction of a Ram Temple further solidified the sentiment of 'Hindu Unity in India, especially in the Hindispeaking states of central, western, and northern India (Ledig, 2020). The Bharatiya Janata Party (BJP)- the political and electoral outfit of the RSS enjoyed significant electoral victories in states and even formed the Central Government in 1998- making it the first time that a right-wing party, more so one with a religious ideology only compatible with the majority Hindu community formed the central government (Kaul, 2017). Hindu leaders, who were 'unapologetic' about the Hindu identity, culture, and nationalism began to emerge at the state level, many of whom would influence national politics severely in the decades to come (Sharma, 2010).

Despite losing a few key elections between 2000 and 2014, the BJP came to power with an unprecedented majority in 2014, which was the first evidence of the 'Rise of the right' in India, a phenomenon that has been observed in many countries over the last decade. BJP continued to dominate state and national politics to emerge as the biggest political force in India (without a close competitor) in less than 10 years. This meteoric rise is based upon BJP's advocacy of the Hindu culture, which they claim to be under threat from Muslim and western influence (Mander, 2018). These arguments are often connected to the partition, and the creation of an Islamic theocratic Pakistan is used as a justification to demand the creation of an India that if not 


\section{International Journal of Social Science and Economic Research}

ISSN: $2455-8834$

Volume:06, Issue:05 "May 2021"

theocratic, is one that is guided by Hindu cultures, ethos, and principles (many of which are inherently discriminatory and oppressive to not just Muslims and Christians but also depressed classes and castes amongst the Hindu fold). Nationalism is at the forefront of discourse, with there being a rise in crimes against minorities, a gradual implementation of Hindu practices in some state processes (such as the involvement of the Prime Minister in the ceremonies surrounding the construction of the Ram Temple), and the curbing of dissent and free speech (Ledig, 2020). The idea of Hindu nationalism and national identity stemming from that seems to be solidified amongst people (especially Hindus in India), given that the BJP has performed successfully in elections despite clearly failing to deliver on the promises of economic prosperity and development.

\section{Conclusion}

The partition of British India was hinged upon the assumption that Hindus and Muslims were culturally so different that they could not form a prosperous nation and exist peacefully in a functional democracy. Post-partition history has proven this wrong time and again. East Pakistan seceded from Pakistan to create a different nation-state (with the help of India, following a violent uprising) due to a conflict that was rooted in cultural and ethnic differences between the Bengali Muslims of East Pakistan and West, as well as problems due to the allocation of resources. On the other hand, Muslims in India, despite having their fair share of problems stemming from religious identity (which have increased progressively over the past decade) has been an integral part of governance and nation-building. The partition caused significant loss of life and property, as well as physical and mental trauma till almost a decade after it was announced. It can be argued that the long-term negative impacts of this program have been even worse. The division of a once united region (based on religion, which is only one of the many key identity markers in the region apart from ethnicity and language) gave rise to religious hatred that has finally begun to surface in India in the 21st century after decades of relative dormancy. Even beyond contributing directly to human rights violations during the actual process of partition, contributing to social instability in Bangladesh and Kashmir, religious divisions stemming from the partition threaten to further cause state-sponsored violence against minorities in the Indian subcontinent. The great exodus during the partition has indeed drained the region of its economic resources, contributed to violence, and deteriorated cultural heritage and its social fabric in the long term.

\section{Bibliography}

Ambedkar, B.R. (1940). Pakistan or the Partition of India. Bombay: Thackers Publishers

Bates, C. (2011). The Hidden Story of Partition and its Legacies. BBC 
International Journal of Social Science and Economic Research

ISSN: 2455-8834

Volume:06, Issue:05 "May 2021"

Brass, P.R. (2003). The Partition of India and retributive genocide in the Punjab, 1946-47:

means, methods, and purposes. Journal of Genocide Research

Butalia, U. (1998). The Other Side of Silence: Voices from the Partition of India. Duke

University Press

Cesari, J. (2014). The Awakening of Muslim Democracy: Religion, Modernity, and the State. Cambridge University Press

Cohen, S.P. (2004). The Idea of Pakistan. Brookings Institution Press.

Gatrell, P. (2013). The Making of the Modern Refugee. Oxford University Press

Jain, J.C. (1987). Gandhi: The Forgotten Mahatma, Mittal Publications

Johari, A. (2018). Facing eviction, residents of a Mumbai Partition-era colony fear they will become homeless again. Scroll

Kaul, N. (2017). Rise of the Political Right in India: Hindutva-Development Mix, Modi Myth, and Dualities. Journal of Labor and Society

Kaur, R. (2007). Since 1947: Partition Narratives among Punjabi Migrants of Delhi. Oxford University Press

Khalidi, O. (1998). From Torrent to Trickle: Indian Muslim Migration to Pakistan, 1947—97. Islamic Studies

Khan, L.A. (1940). Pakistan: The Heart Of Asia. Thacker \& Co. Ltd.

Ledig, E. (2020). Hindutva as a variant of right-wing extremism. Patterns of Prejudice

Mander, H. (2018). New hate crime tracker in India finds victims are predominantly Muslims, perpetrators Hindus. Scroll

O’ Brien, and Cruise, C. (1988). Holy War Against India. The Atlantic Monthly

Savarkar, V.D. (1963). Collected Works of Savarkar, Poona: Hindu Mahasabha

Singh, J. (2009). Jinnah: India-Partition -Independence. Oxford University Press

Sharma, J. (2010) A Review of "The Partition of India," History. Reviews of New Books 
International Journal of Social Science and Economic Research

ISSN: 2455-8834

Volume:06, Issue:05 "May 2021"

Talbot, I., and Singh, G. (2009). The Partition of India. Cambridge University Press

Wood, E. (2000). Feminist Political Thought.

Zamindar, V.F. (2013). India-Pakistan Partition 1947 and forced migration. Wiley Online Library 